\title{
Integrating Mobile Phones in Teaching Auditory and Visual Learners in an English Classroom
}

\author{
Aisha Abdullahi Ibrahim ${ }^{1} \&$ Goodluck Chinenye Kadiri ${ }^{2}$ \\ ${ }^{1}$ Faculty of Education and Extension Services, Department of Curriculum Studies and Educational Technology, \\ Usmanu Danfodiyo University Sokoto, Nigeria \\ ${ }^{2}$ Department of English and Literary Studies, Faculty of Arts, University of Nigeria, Nsukka, Nigeria \\ Correspondence: Goodluck Chinenye Kadiri, Department of English and Literary Studies, Faculty of Arts, \\ University of Nigeria, Nsukka, Nigeria.
}

Received: September 12, 2018 Accepted: November 1, 2018 Online Published: November 3, 2018

doi: 10.5539/elt.v11n12p1 URL: https://doi.org/10.5539/elt.v11n12p1

\begin{abstract}
This paper explores the possibilities of using mobile technology in the teaching and learning of the English language. A sample of 50 Sandwich students/teachers of the English language was drawn through a multi-stage sampling technique. The instrument used to collect data for this study is a ten-item questionnaire on integrating mobile phones in the teaching and learning of English. This instrument was validated by two language experts in the Department of English and Literary Studies, University of Nigeria, Nsukka. Data collected for this study were analysed using the percentage system represented in line charts. The results showed that mobile phones are instrumental in teaching and learning of English in classrooms. The paper concludes that M-learning promotes cooperative and collaborative learning through the enhancement of learner's use of authentic English language that would make it possible for them to construct their own knowledge. Based on the results of this research, the researchers recommend that mobile phone can be integrated in teaching and learning of English as a Second Language.
\end{abstract}

Keywords: M-learning, mobile phones, language teaching, IPods, SMS, GSM

\section{Introduction}

The advent of ICT comes with its attendance to students' accessibility to information. Teaching these learners of this digital age of the 21 st century requires adaptive and technological induced methods by educators. The Global System for Mobile communication (GSM) provides learners greater accessibility to the internet which makes it easier for them to learn under certain controlled situations.

The rise of technology has given birth to a new breed of students who can be referred to as "digital natives" \{an individual who was born after the widespread adoption of digital technology\}. These students have enormous access to digital technology and they display fluency and familiarity with the new technology. They speak the digital language of computers; the Internet; they share and produce digital contents such as blogs, digital images, video files and SMS messages (Tribe, 2004 in Duncan-Howell \& Lee, 2007). These students are growing with a glut of electronic media use and this differentiates them from previous generations of students whose learning experiences were dominated by text in books and journals. As they consume more images and sounds along with the text that they learn, they also interact with the technology more than previous generations. The lives of these digital natives are influenced by mobile phones which seem to be the fastest growing technology in recent times.

The mobile phone which was introduced roughly 25 years ago now has more than 6.6 billion connections in use (BBC News 2011). In Nigeria, there are 93 million mobile phone subscribers, (BBC News, 2011) and younger people aged fewer than 25 have been reported to be more users of the mobile phone than older people, (ITU, 2011). With the prevalence of mobile phones, more especially their handiness and their easy access to information for young people, it is obvious that these developments in Information and Communication Technologies (ICT) have evolving learner behaviours. This requires educators to continuously review their approaches to pedagogy. With the increasing availability of low cost mobile phones, it seems appropriate to focus on the potentials of using the mobile technologies in teaching and learning practices in making education more accessible, more efficient, more cost-effective and more enjoyable. 


\subsection{Literature Review - M-learning: Teaching and Learning Through Mobile Technologies}

Teaching and learning through Mobile Technologies (MT) is called M-learning. It allows learning in no fixed location or time of learning (Kinshuk, 2003). It is a type of teaching and learning that allows for flexibility and ubiquity. It allows for a more student centered approach in learning where the student is more responsible for acquiring, processing and using information. It also allows for increased interactivity between teachers and students, thereby making teaching and learning a more personal activity.

Nyiri (2002) defines M-learning "as learning that arises in the course of person-to-person mobile communication". This type of pedagogy involves the use of phones, IPods, Personal Digital Assistants (PDAs), it does not, however, include the laptop because the laptop though portable, is not mobile.

Gaudry-Perkins and Dawes, (2011) state that mobile learning ranges from "simple SMS messaging, MMS, live classroom sessions, web and podcasting to audio-to-text or text-to- audio applications, and it can provide enriched learning experiences via "educational video, logical reasoning and problem solving aptitude games, and even mobile whiteboards for interactive discussions."

Teaching and learning through mobile technologies afford the option of mobility both due to the structure of the device and of the participants involved. This distinctive feature offers a transition from the occasional, supplemental use of computer labs, to frequent and integral use of portable computational technology (Roschelle, 2003). It bridges the gap between formal and informal learning. Similarly, it allows an increased mobility of population and lifelong learning, thereby creating opportunities for constant practice anywhere and anytime. This access to technology is important especially in the teaching of English as a Second Language because it enables the learners to constantly practice the language. It also aids the easy recollection of what has been taught, thereby making it possible for learners to put into practice the learnt concepts in real life situations. In addition, it allows for variety and creativity in teaching and learning, thereby increasing interaction and interactivity between teachers and students which brings about creativity and critical thinking. Furthermore, it allows the student to be more responsible in his acquisition of information; he is more active in getting his own education (Kukulska-Hulme, Shield, \& Hassan, 2010).

M-learning is often regarded as a subset of e-learning and is seen as good supplement to e-learning or face to face interaction. M-learning can never replace traditional education or the role of teachers, it is a tool that can help to make tremendous impact on education more accessible, more efficient, more cost-effective especially in developing countries, and more enjoyable.

Although using mobile technologies in education is a fairly new field, especially in Africa, when compared to areas like health and agriculture; various studies have been carried out to examine the viability of using mobile technologies for pedagogical activities in educational institutions.

\section{Methods}

The study adopts a descriptive survey design because it allows a researcher to select a representative sample from the entire population of the study. The sample of the study comprised fifty (50) Sandwich students in the Department of English and Literary Studies, University of Nigeria, Nsukka, who also teach English in different secondary schools across the country. The questionnaires were analysed quantitatively using the simple percentage system represented in line charts.

\subsection{Validation of Instrument}

The instruments for data collection were validated by two experts in the Department of English and Literary Studies, University of Nigeria, Nsukka. The experts affirmed that the instruments were appropriate and suitable in this research.

\section{Results}

Table 1 indicates that $48 \%$ of respondents agreed that cell phone is instrumental in the teaching and learning of language contents via cell phone note feature. Another $36 \%$ strongly agreed to the same proposition. However, only $16 \%$ disagree that cell phone is instrumental in teaching language related contents. From this interpretation, majority of the respondents represented by $84 \%$ by extension, therefore, were in agreement that mobile phone note feature aids the teaching and learning of language contents. 


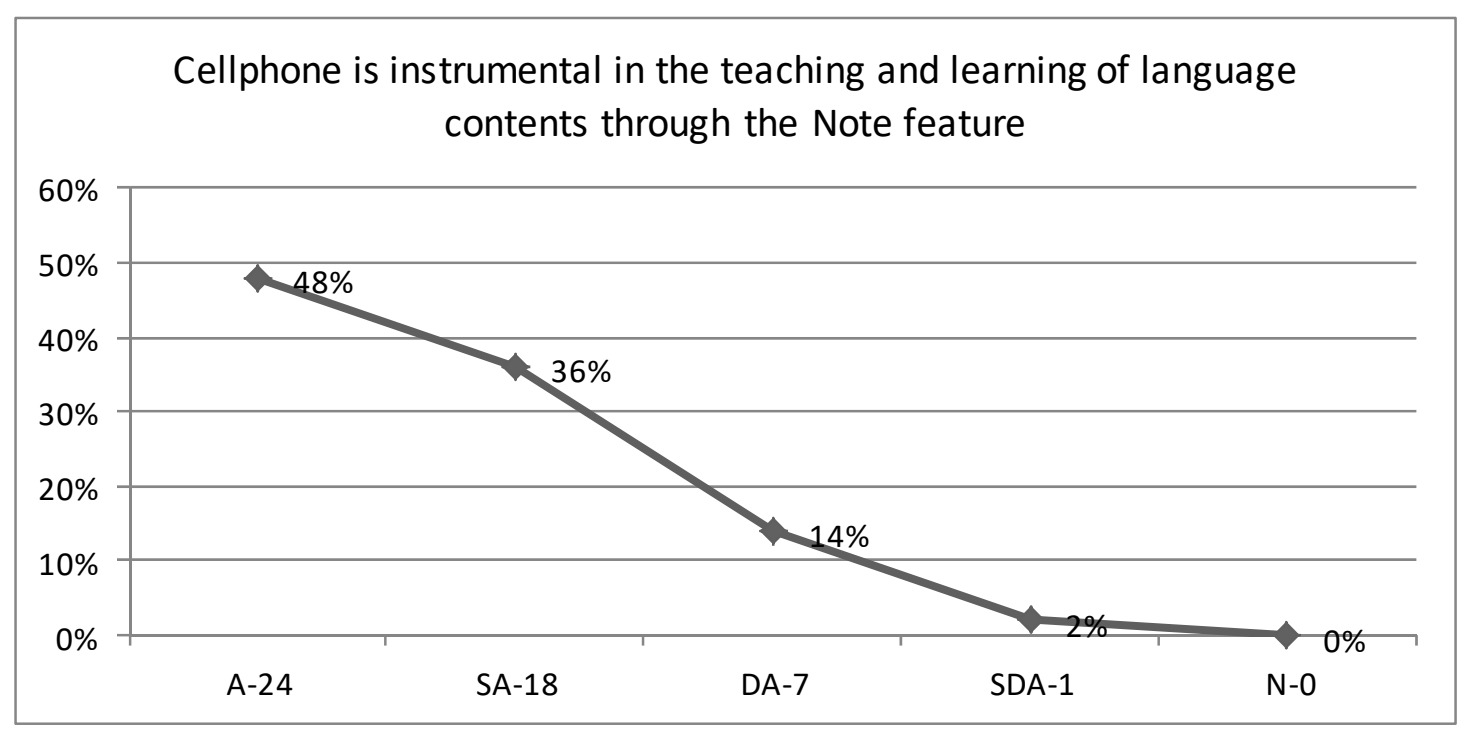

Figure 1. Cell phone is instrumental in the teaching and learning of language contents through note feature

Figure 2 shows that $82 \%$ conceded that cell phone concretizes the abstract aspects of language instructions; while $18 \%$ argued against the proposition. It is, thus, concluded that the majority are in agreement that mobile phones reduce the abstract nature of language instruction through games.

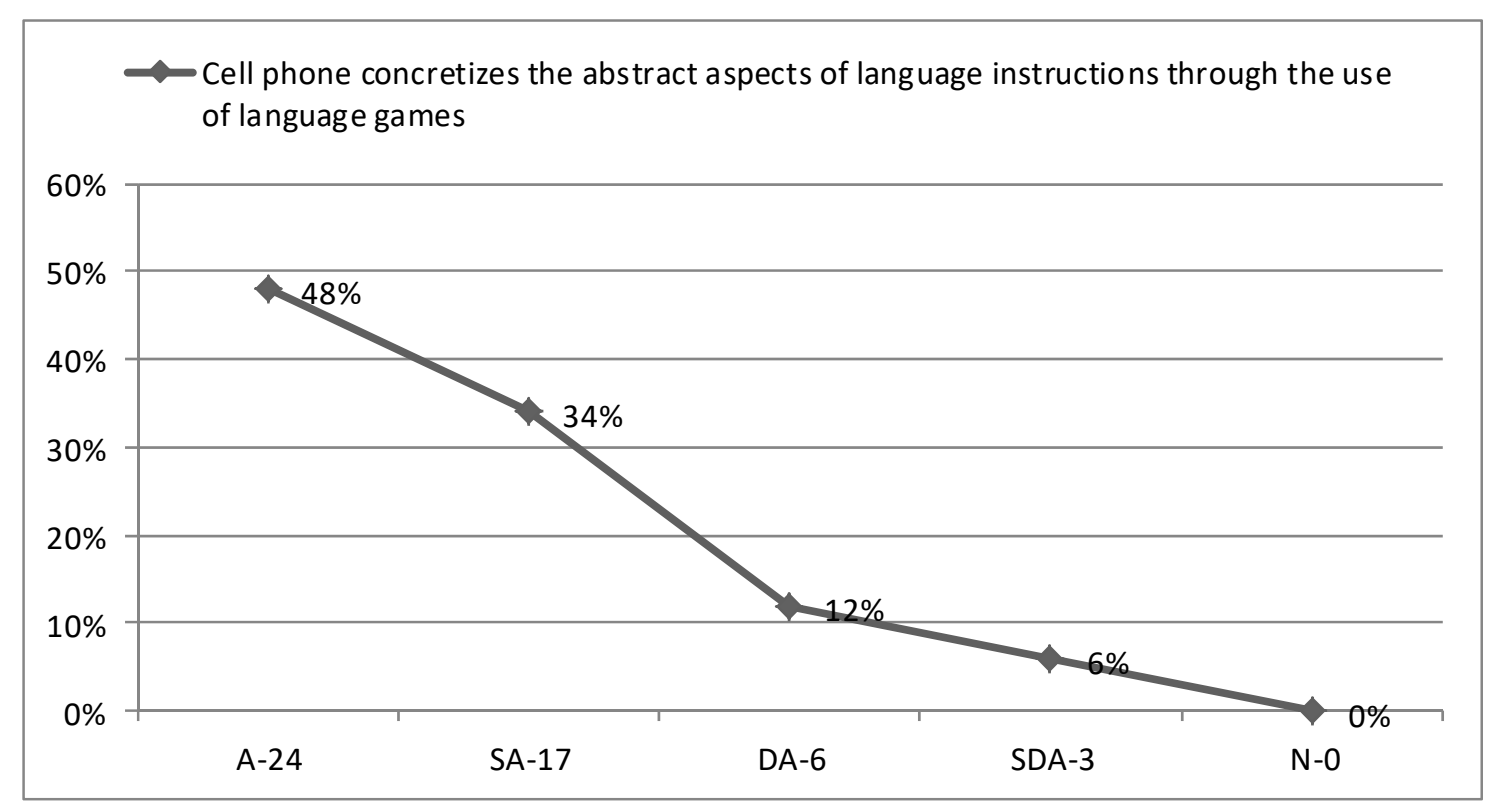

Figure 2. Cell phone concretizes the abstract aspects of language instructions

Figure 3 reveals that majority of the respondents represented by $94 \%$ agreed that Cell phone aids slow-learners in speedily internalizing the teaching of vocabulary through the use of phone dictionaries; while just 3 respondents represented by $6 \%$ disagreed. It is, therefore, evident that cell phone aids slow learners in language classes. 


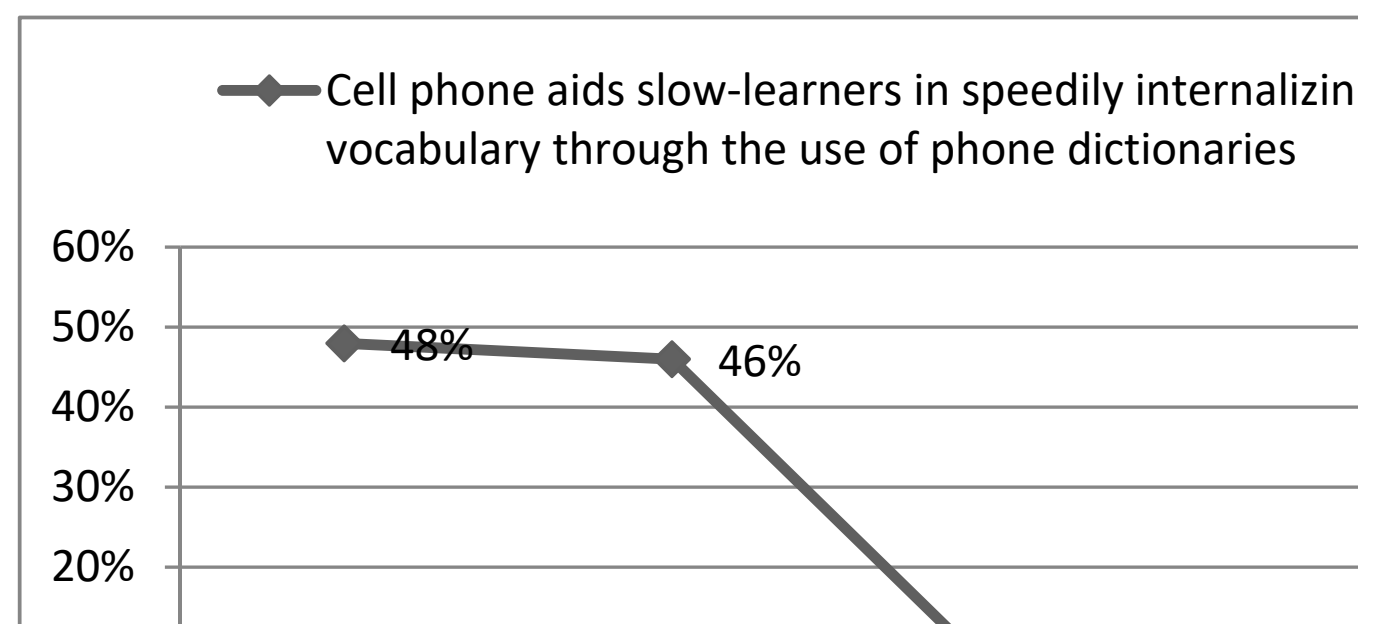

Figure 3. Cell phone aids slow-learners in speedily internalizing the teaching of vocabulary

Figure 4 indicates that $78 \%$ agreed that cell phone enhances the teaching of language error and error analysis. However, $20 \%$ argue against the proposition. It is, therefore, concluded that cell phone audio recorder plays important role in teaching error and error analysis.

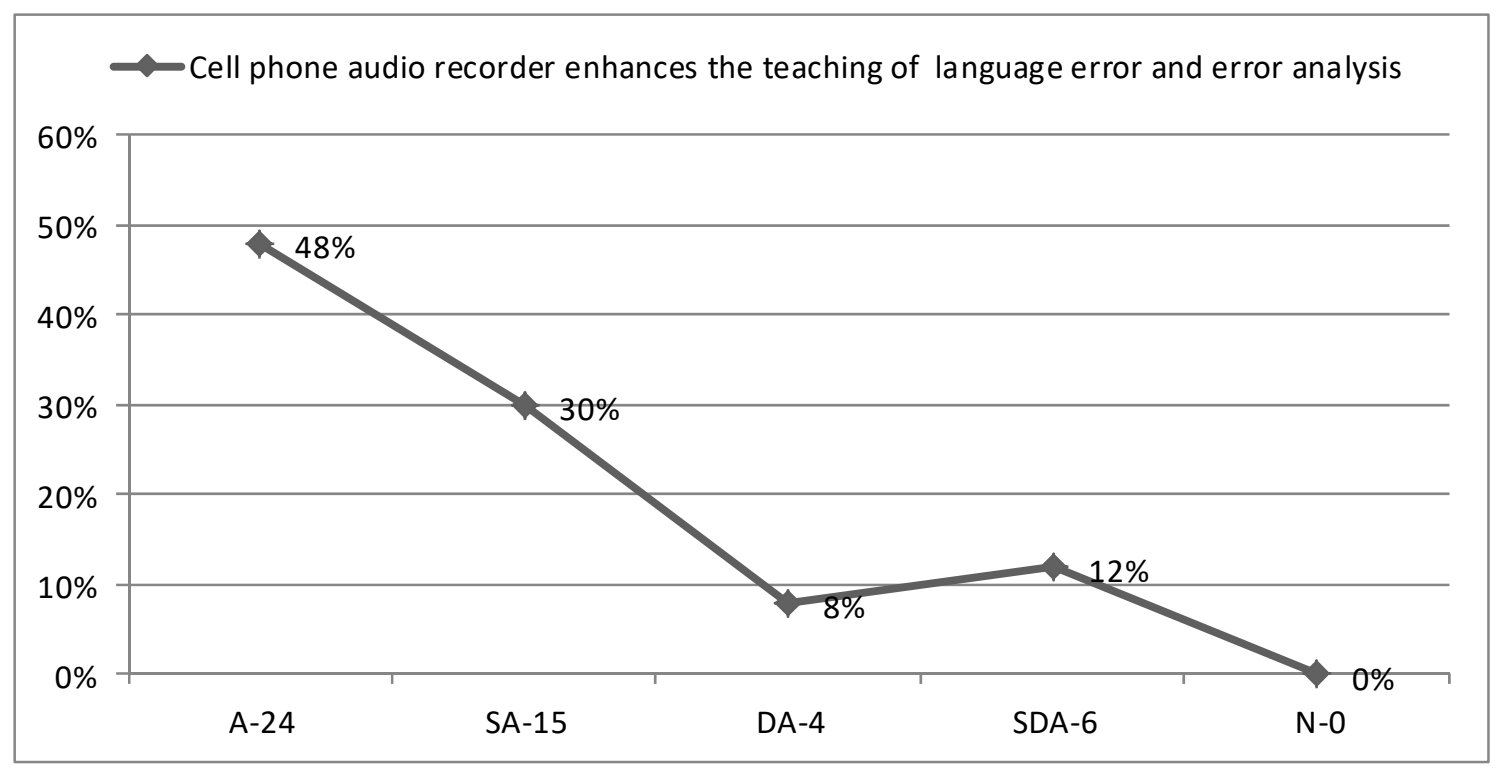

Figure 4. Cell phone enhances the teaching of language error and error analysis

Figure 5 indicates that $88 \%$ of the respondents are in agreement that Synchronous language interactions increase high level of performance in teaching and learning morphology and syntax; while a handful of respondents represented by $10 \%$ disagreed. However, $2 \%$ of the respondents remained undecided. From this interpretation, mobile phones connected for synchronous interaction in language class increase high level of performance. 


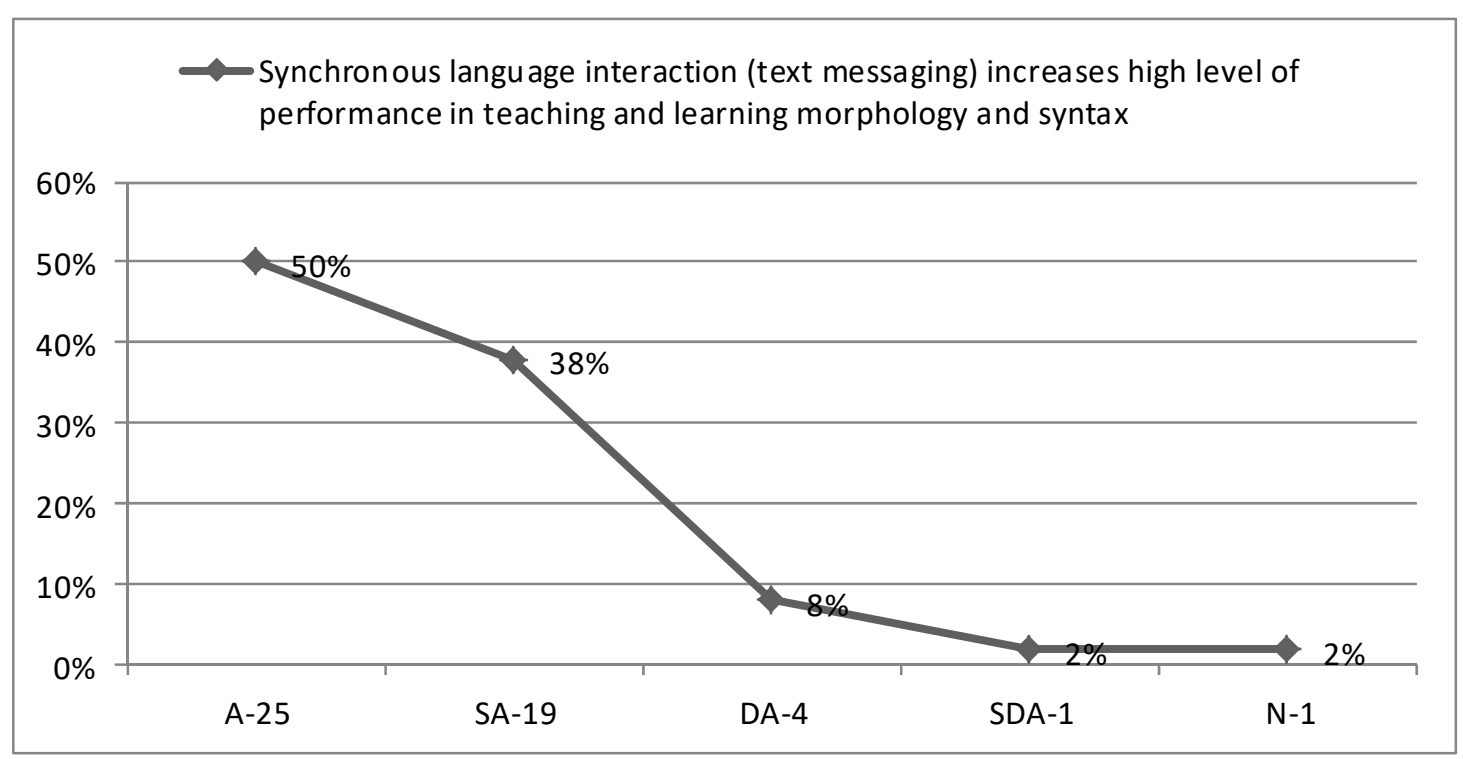

Figure 5. Synchronous language interactions increase high level of performance in teaching and learning morphology and syntax

Figure 6 indicates that $46 \%$ of respondents agreed that cell phone English phonological Application facilitates the teaching and learning of English phonemes. Another $40 \%$ strongly agreed to the same proposition. However, only 14\% disagreed that cell phone English phonological Application facilitates the teaching and learning of English phonemes. From this interpretation, the majority of the respondents represented by $86 \%$ by extension, therefore, were in agreement that mobile phones aid the teaching and learning of language contents.

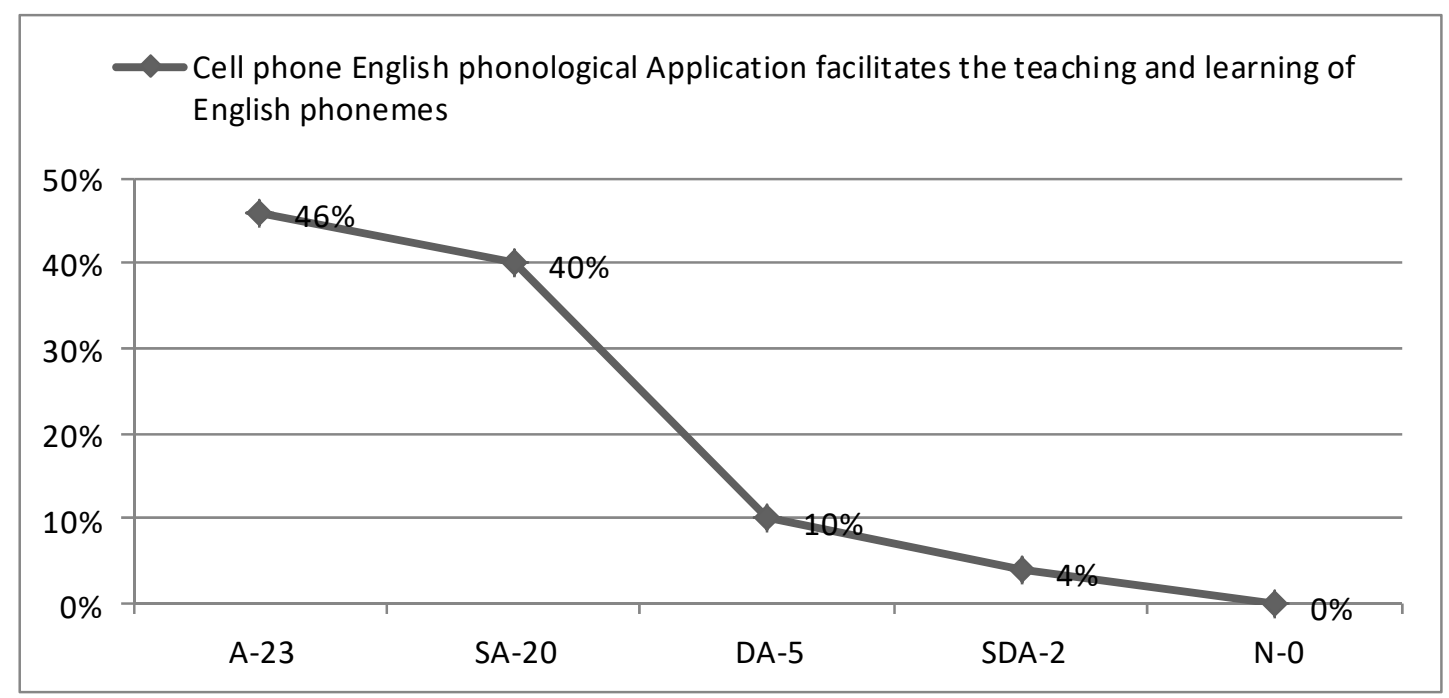

Figure 6. Cell phone English phonological application facilitates the teaching and learning of English phonemes

Figure 7 shows that $84 \%$ agreed that checking and correcting spelling mistakes using cell phone is an added advantage in English language class; 16\% argued against the proposition. It is, thus, concluded that the majority are in agreement that correcting spelling mistakes using cell phone is an added advantage in English language class. 


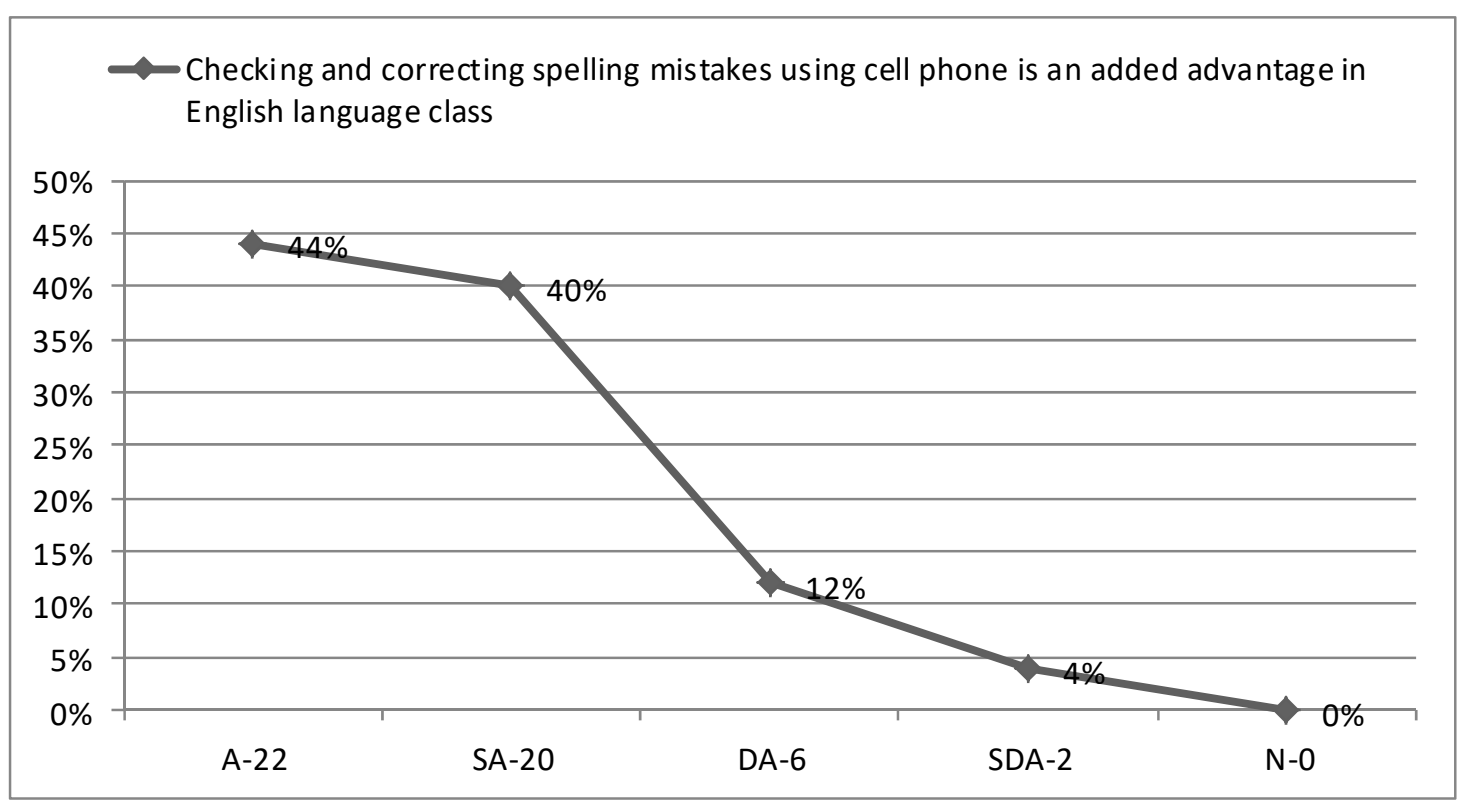

Figure 7. Checking and correcting spelling mistakes using cell phone is an added advantage in English language class

Figure 8 reveals that the majority of respondents represented by $80 \%$ agreed that the cell phone has writing templates that assist students during written composition session; while 15 respondents represented by $30 \%$ disagreed. It is, thus, evident that cell phones aid slow learners in composition classes.

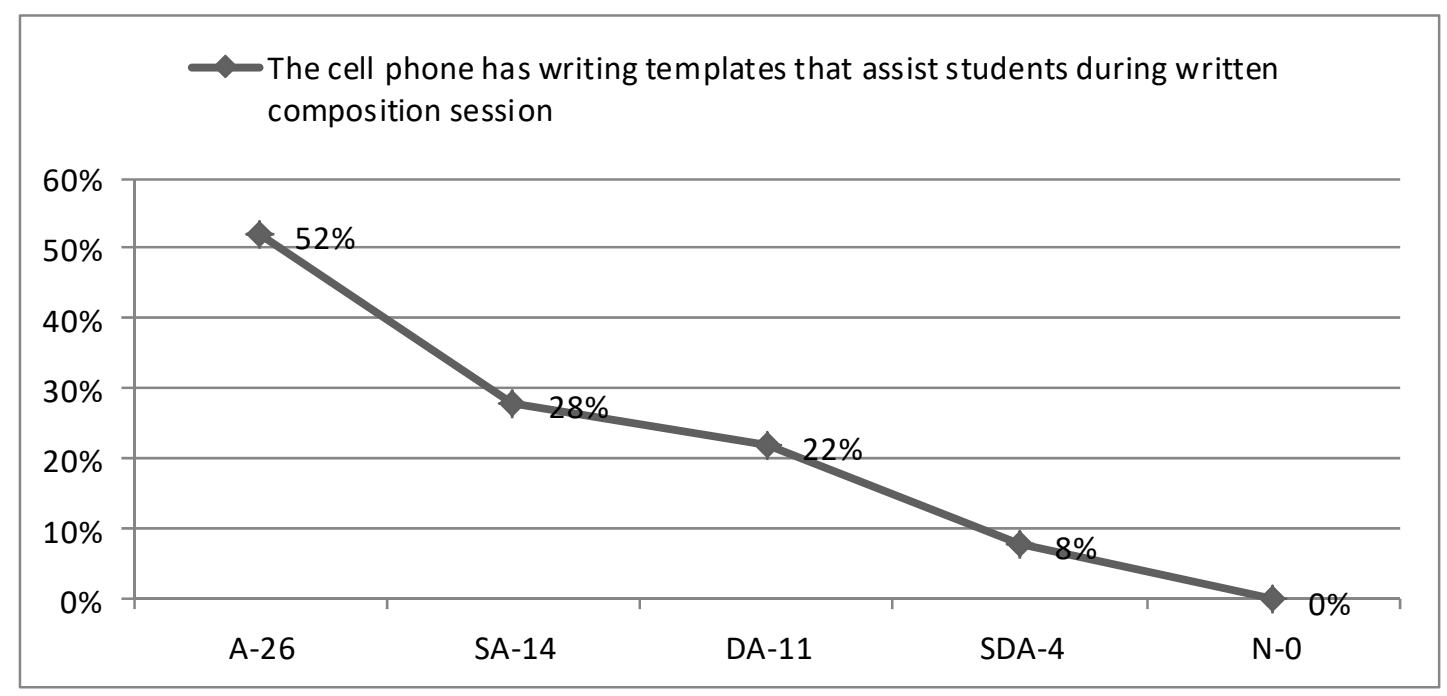

Figure 8. Cell phone has writing templates that assist students during written composition session

Figure 9 indicates that $36 \%$ of respondents agreed that Abbreviations and acronyms are better taught using cell phones. Another $28 \%$ strongly agreed to the same proposition. However, $36 \%$ disagreed that Abbreviations and acronyms are better taught using cell phones. From this interpretation, majority of respondents represented by $54 \%$ by extension, therefore, were in agreement that mobile phones aid the teaching and learning of abbreviations and acronyms. 


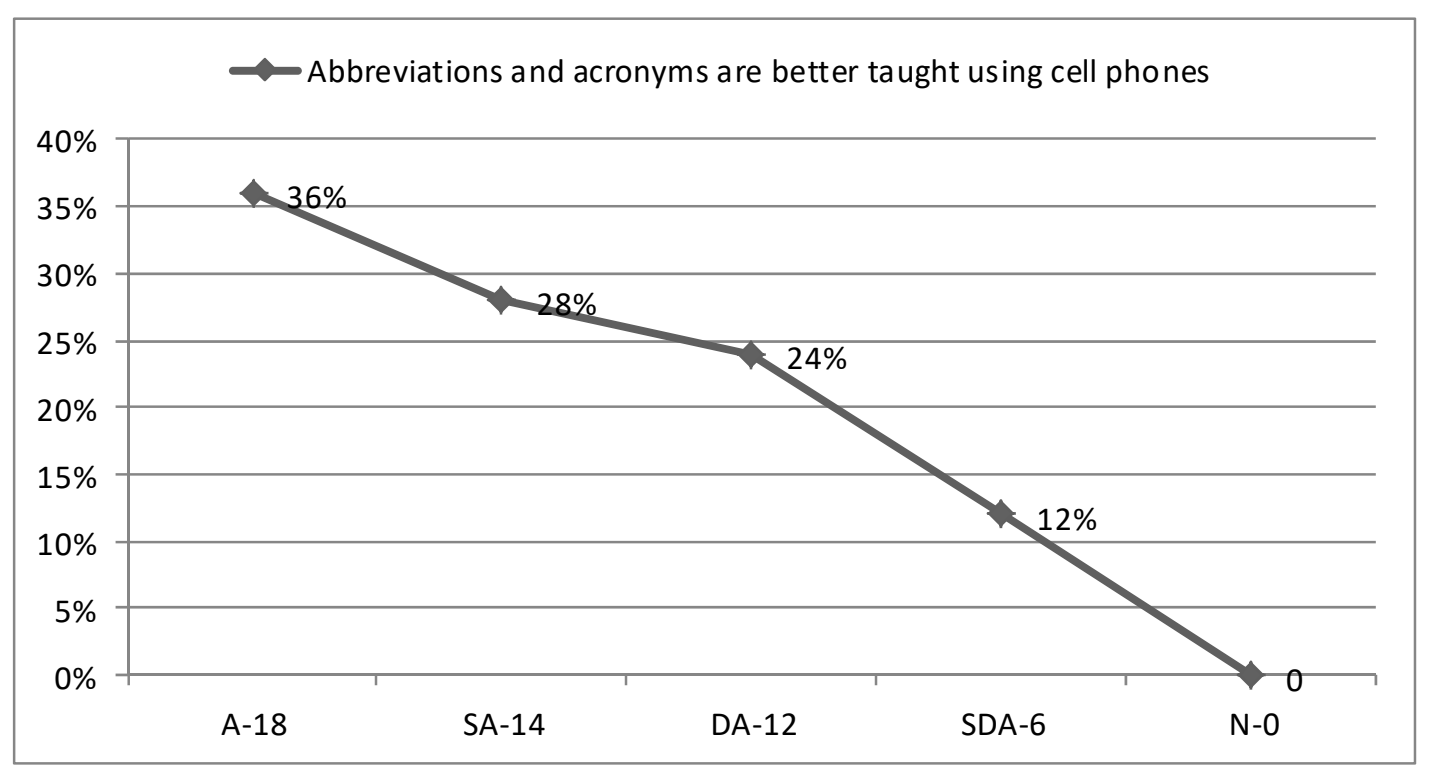

Figure 9. Abbreviations and acronyms are better taught using cell phones

Figure 10 shows that $86 \%$ of the respondents agreed that scenes are better described in essays using camera and video shots. However, only $14 \%$ disagreed that scenes are better described in essays using camera and video shots. From this interpretation, the majority were in agreement that imagery scenes are better described in essays using camera and video shots.

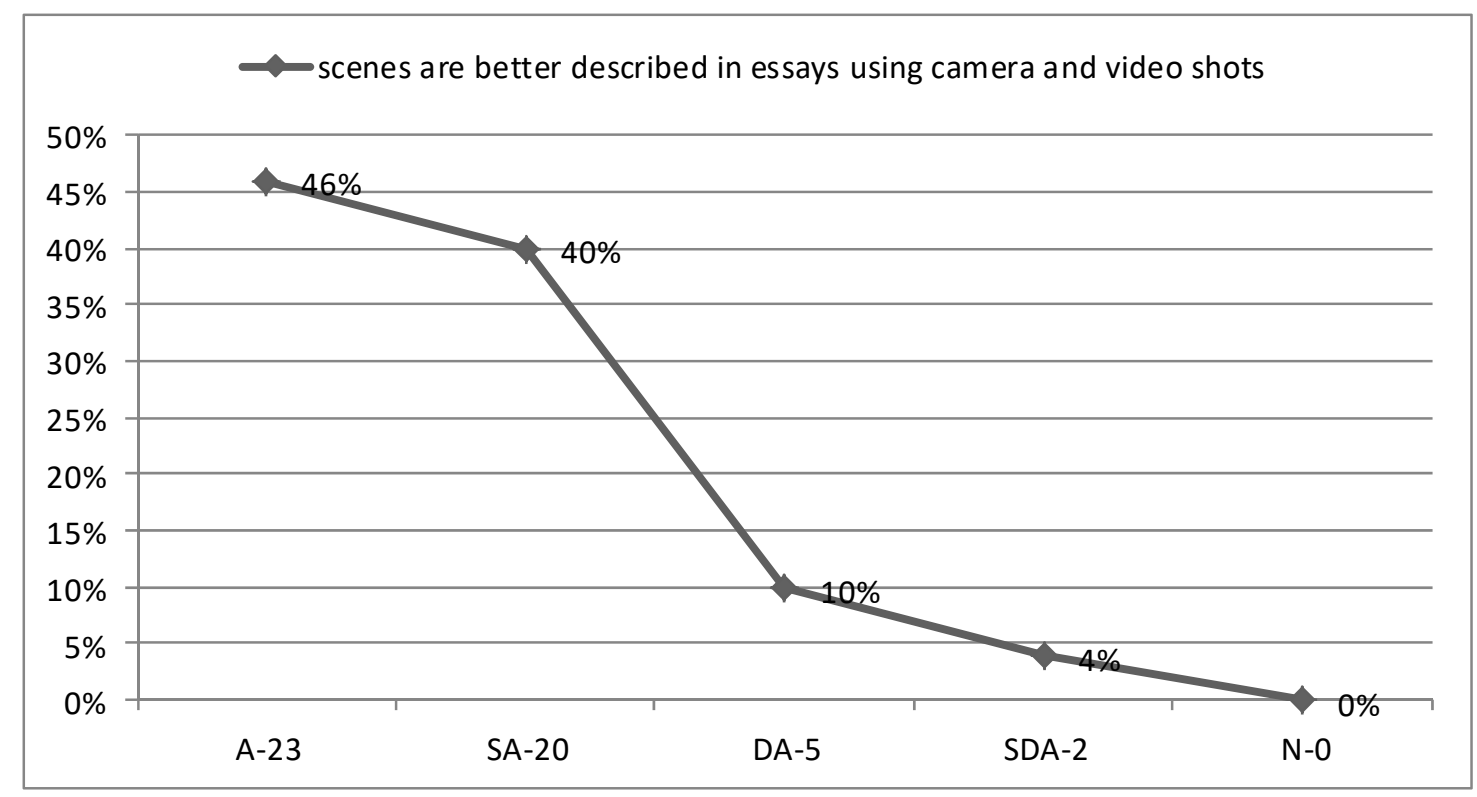

Figure 10. Scenes are better described in essays using camera and video shots

\section{Discussion}

From the data generated, we would like to discuss how this mobile phone can be used inside the classroom for the teaching and learning of English language; taking into consideration the features of the mobile phone.

\subsection{Note Feature}

Note is a valuable feature. It can be used to take notes. English language can be acquired from watching movies, 
listening to news, by reading books and newspapers etc. No wonder many respondents agreed that this feature aids the teaching/learning of language content. When we come across a new word, or structure, or an expression we can immediately save them in the mobile phone by using the note feature. Frequently or occasionally, it can be revised as we cannot keep everything in our memory. In the class, the teacher can ask the students to present what they have collected in their note feature. The students should be taught and encouraged to use the new words and expressions in their conversation.

\subsection{Text Messages}

Communication is an important skill to be practiced in English classes. We can create fun in the classroom by making the students send text messages among themselves either synchronously or asynchronously. The teacher can divide the class into heterogeneous groups. A theme can be given to each group. The group members should send their opinions regarding the topic in simple sentences. The group leader collects and consolidates all the messages sent by the members and holds an open discussion with the members and presents it in the class. By so doing, students learn how to organize and express their thoughts and ideas in simple language. Teacher corrects the mistakes at the end of each presentation.

\subsection{Camera}

Beautiful pictures, natural sceneries and scenes that captivate the mind when the students are taken to field trips or educational tours can be captured by using camera. Back to class, they can be used for group discussions. Teacher can make the students speak or write about their personal experience by using the pictures. Enthusiastically, they involve themselves in the activity and express their feelings and experience in their own language. This will definitely develop their English language skill. Images, thus captured, can be used for making albums, project works etc. It can also be used as flash cards for teaching new words. Front facing cameras allow learners to be creative as well as enabling them to trigger the release of information.

\subsection{Voice Recorder}

It is a very useful facility available on mobile phones. This probably explains why majority of the respondents agreed that cell phone audio recorder enhances the teaching of language error and error analysis at the level of phonology. It facilitates one to record speech sounds in the mobile phone. One can record the conversation and replay it. It is a very useful tool that a teacher can use inside the classroom. Of the four skills of English language, listening is the basic skill. Only heard sounds are produced, those unheard are never produced. Hence, it is mandatory to give listening practice to learners of a foreign language. Mobile phone is a very simple and convenient tool to do this. Teacher can record or download audio clippings from internet or movies and play it inside the classroom. Students can be made to listen to it carefully and questions can be asked to check their comprehension skill.

Hence, students get a chance to listen to an English speech or conversation or a debate. It helps them imitate correct speech sounds and pick up appropriate vocabulary and language structures in their usage. Students learn how ideas are presented coherently. It will definitely improve their style of speech and get them familiar with the native speaker's voice and accent.

\subsection{Video Recorder}

Another important tool available on the mobile phone is the video recorder. Video clippings regarding day to day events, important happenings in the country, scenes from the plays and movies can be imported from the internet and played for the students. Important movie clippings related to the lesson can be clipped and saved in the mobile phone. Students can be asked to watch the clippings and may be asked to describe in writing or speech what they have watched. Videos of historical plays, classical works and recitation of famous poems are available on net. Teachers can download those videos and play them to the students.

\subsection{Internet}

Internet also can be connected to a mobile phone. Students can surf the net for getting notes, pictures, PowerPoint presentations, extra reading materials etc. Most of the presentations, video and audio clippings available on net are mobile friendly. It can be downloaded and used for learning.

\subsection{Mobile Dictionary}

Mobile dictionary is a mobile application that translates words from one language to another. The application allows having English and two additional languages on the device at the same time. While reading, students may come across many new words. By using the mobile dictionary they can find out the meaning of the words. Reference work is made easy with this facility on the mobile. 


\section{Benefits of Using Mobile Phone}

\subsection{Preparing Students for the Future: Eliminate Technophobia}

First and foremost your job as an educator is to prepare your students for the future. In order to do so, you need to incorporate mobile technology in the classroom. Working with mobile devices will not only be a part of their everyday lives as adults, but it will also be a vital part of many career paths. Knowing how to appropriately use mobile devices is an important aspect in this increasingly connected world. In order to properly prepare your students for the future as they transit into the workforce; incorporating mobile technology in the classroom, providing school wireless networks - Wi-Fi services is key classroom technology.

\subsection{Up-to-date Learning}

The old days of looking for information in encyclopaedias are long gone. Having mobile devices in the classroom allows students instant access to the latest news, information, statistics, etc. Virtually every question they have is at their fingertips, keeping them connected with what is going on around them and ensuring they are always well informed with the most up-to-date information.

\subsection{Alternative to Textbooks}

Many textbooks are not the most relevant sources of information. Today's generation has grown accustomed to instant, updated information. Textbooks cannot provide students with the latest information like a mobile device can.

\subsection{Learning Goes Outside of the Classroom}

By allowing mobile devices in schools you can expand learning outside of the classroom. Students will not only have access to information during computer lab time (which is also becoming extinct); they can look up information from anywhere on campus. Collaboration will increase as students can use these devices as research tools during projects and group work. Students love technology so they are likely to be excited about it and continue learning outside of school hours. Having those learning apps, digital textbooks, etc. on mobile devices allow them to get extra studying and learning outside the school.

\section{Challenges}

1) All the students may not have mobile phones with them.

2) Activities such as browsing the internet, sending messages, making calls will cost money.

3) Not all mobile phones have the features listed above.

4) Data package may not be readily available for school usage.

5) Parents may not be financially capable to provide their children with data package.

6) Students may not use the mobile phone for education purposes only.

7) Some parents may not approve of the young wards to use mobile phones.

8) Teachers cannot control what other things students access with their mobile phones.

9) Irregular Network Connections.

10) Lack of constant power supply to charge the Mobile phones.

\section{Suggestions}

a) For young learners, the consent of the parent is necessary for using mobile phones in the school.

b) Keen observation of the teacher is mandatory; otherwise the use of mobile phone may divert the attention of the students to unnecessary web sites.

c) School can create Solar Energy Panels for regular power supply and phones charging point in the school for the students to charge their phones.

d) School management can secure grants for data package from established companies; donor agencies etc. to enable students have free access internet resources.

e) Federal and State Ministries of Education can align with manufacturing companies to produce desired but affordable mobile phones for students use.

f) Every technology has its own good and bad effects. We need to recognize them and tap them for good ends. Mobile phone also has its own good and bad effects. If we brilliantly plan, we shall use them for learning and 
evaluating the language skills. Proper plan and judicious use of the mobile phone will definitely bring about desirable learning outcomes.

\section{Conclusion}

The paper concludes that M-learning is cooperative, collaborative and learner centered. It enhances active involvement of the students in the acquisition of linguistic knowledge as it gives the learners the chance through networks and different forums to gather, post and share ideas and other resources. The opportunity given by M-learning would afford the learners of the chance of using authentic English language that would make it possible for them to construct their own knowledge. The integration of M-learning in the teaching of English would afford the learners the opportunity of having a method that is 21 st century compliant and availing the learners the digital age benefits.

\section{Acknowledgements}

We thank the fourth year Sandwich students of the University of Nigeria, Nsukka who willingly filled out the questionnaires. We thank Joekin Ekwueme who assisted in conducting the study. We also acknowledge those who assisted in one way or the other and the authors whose works made impact in this study.

\section{References}

Al-Mutawa, N., \& Kailani, T. (1989). Methods of teaching English to Arab students. Longman Group Ltd.

BBC NEWS. (2011). Africa mobile phone industry "booming". Retrieved August 20th, 2012, from www.bbc.co.uk/news/world-africa- 1565998

Brown, T. (2005). Towards a model for m-learning in Africa. International Journal on E-Learning, 4(3), 299-315.

Chinnery, G. (2006). Going to the MALL: Mobile assisted language learning. Language Learning and Technology, 10(1), 9-16.

Duncan-Howell \& Lee. (2007). M-learning: Finding a place for mobile technologies within tertiary educational settings. Retrieved June 11th, 2012, from www.ascilite.org.au/conferences/singapore07/procs/duncanhowell.pdf

Gaudry-Perkins, F., \& Dawes, L. (2011). A powerful tool for addressing MDGs. Retrieved 2012 from www.mdg-review.org

Geddes, S. J. (2004). Mobile learning in the 21st Century: Benefit to learners. Retrieved August 3rd, 2012, from $\mathrm{http} / / /$ knowledgetree.flexible learning.net.au/edition06/download/geddes.pdf

Hartnell, Y., \& Nadja, H. (2008). How mobile phones help learning in secondary Schools. A Report to Becta. Learning Sciences Research Institute University of Nottingham. Retrieved June 29th, 2012, from www.isri.nottingham.ac.uk

ICT Facts and Figures. (2011). ITU world telecommunication/ICT Indicators database. International Telecommunication Union.

Isiaka R. M., Adewode, K. S., \& Olayemi, R. T. (2011). Implementing mobile learning in Nigeria tertiary educational system - A feasibility study. International Journal of Science and Advanced Technology, 1(7), 84-90.

Johnson, K., McHugo, C., \& Hall, T. (2006). Analysing the efficacy of blended learning using technology enhanced learning (TEL) and m-learning delivery technologies. Paper presented at the 23rd ASCILITE Conference, Sydney, 3-6 December 2006.

Keegan, D. (2005). Mobile learning: next generation of learning. Distance Educational International. Retrieved June 29th, 2012, from http://learning.ericsson.net/mlearning2/files.

Reinders, H. (2010). Twenty Ideas for Using Mobile Phones in the Language Classroom. Retrieved from http://exchanges.state.gov/englishteaching/forum/archives/docs/forum-10-48-03/48_3_4_reinder

\section{Copyrights}

Copyright for this article is retained by the author(s), with first publication rights granted to the journal.

This is an open-access article distributed under the terms and conditions of the Creative Commons Attribution license (http://creativecommons.org/licenses/by/4.0/). 